\title{
Clinical-epidemiological characteristics associated with discharge outcomes and seasonality among surviving patients with Guillain-Barré syndrome in a national third- level hospital, Lima, Perú
}

Características clínico-epidemiológicas asociadas con los resultados al alta y la estacionalidad entre los pacientes sobrevivientes con síndrome de Guillain-Barré en un hospital nacional de tercer nivel, Lima, Perú

Victor VELÁSQUEZ-RIMACHII,2,3, Angélica Verónica LÓPEZ-SAAVEDRA ${ }^{1,2,4}$, Ethel RODRIGUEZ-LÓPEZ ${ }^{1,2,4}$, Hillary ELGUERA-HUAMAN ${ }^{1,4}$, Kelly MEZA ${ }^{5}$, Carlos ALVA-DIAZZ,6, Kevin PACHECO-BARRIOS ${ }^{7,8}$

\begin{abstract}
Background: Guillain-Barré syndrome (GBS) is an autoimmune disease that affects the peripheral nervous system. Severe motor deficit (SMD), respiratory impairment, cranial nerve involvement and autonomic dysfunction are associated with a poor prognosis. Objective: To investigate the association between the clinical-epidemiological characteristics and the discharge results among Peruvian patients with GBS. Methods: We carried out a retrospective observational study on patients with GBS who survived until discharge. We used the Brighton Collaboration's criteria and considered Hughes Severity Scale (HSS) scores greater than two to be SMD. We defined the discharge results as an improvement if the HSS score decreased by at least one point from admission to hospital discharge and defined hospital stay as prolonged if > 14 days. Results: We analyzed 92 patients, among whom 70.7\% were male. Quadriparesis (81.1\%) and hyporeflexia (86.8\%) were the most characteristic manifestations. We observed that more than half of the cases were in summer and winter. Gastrointestinal infections were associated with a higher proportion of prolonged stays. The proportion of improvement was lower among patients who had an SMD at hospital admission. We confirmed these results through fitting in multivariate models. Conclusions: The prolonged stay was related to previous gastrointestinal infection, while a less improvement in SMD individuals at admission. Prospective multicenter surveillance systems are needed for monitoring GBS cases in low-income settings like Peru.
\end{abstract}

Keywords: Guillain-Barré Syndrome; Seasons; Peripheral Nervous System.

\section{RESUMEN}

Antecedentes: El síndrome de Guillain-Barré (SGB) es una enfermedad autoinmune que afecta al sistema nervioso periférico. Déficit motor severo (DMS), compromiso respiratorio, afectación de pares craneales y disfunción autonómica se asocian con un mal pronóstico. Objetivo: Investigar la asociación entre las características clínico-epidemiológicas y los resultados del alta en pacientes peruanos con SGB. Métodos: Realizamos un estudio observacional retrospectivo de pacientes con SGB supervivientes hasta el alta. Consideramos los criterios de colaboración de Brighton y una escala de severidad de Hughes (ESH) superior a dos como un DMS. Definimos los resultados del alta como una mejoría si el ESH disminuyó en al menos un punto desde el ingreso hasta el alta hospitalaria y una estadía prolongada

\footnotetext{
'Universidad Nacional Mayor de San Marcos, Facultad de Medicina, Lima, Peru.

${ }^{2}$ Red de Eficacia Clínica y Sanitaria, Lima, Peru.

${ }^{3}$ Universidad Científica del Sur, Grupo de Investigación en Neurociencia, Efectividad Clínica y Salud Pública, Lima, Peru.

4 Universidad Nacional Mayor de San Marcos, Sociedad Científica de San Fernando, Lima, Peru.

${ }^{5}$ Weill Cornell Medicine, Department of Pediatrics, Division of Pediatric Nephrology, New York NY, USA

${ }^{6}$ Universidad Científica del Sur, Facultad de Ciencias de la Salud, Lima, Peru.

`Universidad San Ignacio de Loyola, Unidad de Investigación para la Generación y Síntesis de Evidencias en Salud, Lima, Peru.

${ }^{8}$ SYNAPSIS Mental Health and Neurology Non-Profit Organization, Lima, Peru.

VVR (D) https://orcid.org/0000-0002-9350-7171; AVLS (10 https://orcid.org/0000-0002-5235-9117; ERL (D) https://orcid.org/0000-0003-4842-9116; HEH (iD) https://orcid.org/0000-0003-0887-6093; KM (D) https://orcid.org/0000-0002-1777-2360; CAD (D) https://orcid.org/0000-0003-3584-7298;

KPB (1) https://orcid.org/0000-0002-7166-2816

Correspondence: Angélica V. López-Saavedra; Email: angelicavlopezsaavedra@gmail.com.

Conflict of interest: There is no conflict of interest to declare.
}

Authors' contribution: VVR: conceived and designed the analysis; ALS, ERL, HEH: collected the data; VVR, KPB: performed the analysis; VVR, ALS, ERL, HEH, KM: wrote the paper; CAD, KPB: gave expert advice. All authors approved the final version for publishing.

Received on April 11, 2020; Received in its final form on November 10, 2020; Accepted on November 13, 2020 
si el tiempo de hospitalización fue > 14 días. Resultados: Analizamos 92 pacientes, de los cuales el 70,7\% eran varones. La cuadriparesia $(81,1 \%)$ y la hiporreflexia $(86,8 \%)$ fueron las manifestaciones más características. Observamos más de la mitad de los casos en verano e invierno. Las infecciones gastrointestinales se asociaron con una mayor proporción de estadías prolongadas. La proporción de mejoría fue menor en los pacientes que tenían un DMS al ingreso hospitalario. Confirmamos estos resultados con modelos multivariados ajustados. Conclusiones: La estadía prolongada se relacionó con infección gastrointestinal previa, mientras que una mejoría menor en individuos con DMS al ingreso. Necesitamos sistemas de vigilancia multicéntricos prospectivos para monitorear los casos de SGB en un entorno de bajos ingresos como Perú.

Palabras clave: Síndrome de Guillain-Barré; Estaciones del Año; Sistema Nervioso Periférico.

\section{INTRODUCTION}

Guillain-Barré Syndrome (GBS) is a disease of autoimmune etiology mediated by autoantibodies that primarily affects the myelin of the peripheral nervous system. It is one of the principal causes of acute flaccid paralysis and may present with axonal injury ${ }^{1-3}$. Its onset may be acute or subacute, characterized by ascending progressive weakness that initially has distal and centripetal distribution and which affects the lower extremities more than the upper extremities. This syndrome can compromise ventilatory muscles, and ventilatory support is required for up to $30 \%$ of patients in intensive care units ${ }^{4,5}$.

GBS affects about 1.1 per 100,000 people worldwide annually $^{3}$. In South America, Chile reported a prevalence of 2.1 cases per 100,000 ${ }^{6}$; and in Peru, the incidence varied from 0.62 to 0.92 per 100,000 habitants between 2016 and 2019, and it was higher among men and in people over 60 years of age ${ }^{7}$.

Demyelinating acute inflammatory polyradiculopathy, acute motor axonal neuropathy, acute motor-sensitive axonal neuropathy and Miller-Fischer syndrome (MFS) are phenotypic variants of the clinical and neurophysiological characteristics of $\mathrm{GBS}^{3}$. In Peru, acute motor-sensory axonal neuropathy is the most frequent phenotype $(37.5 \%)^{8}$.

Campylobacter jejuni and Haemophilus influenza infections are the most frequent infectious histories associated with GBS. Nevertheless, infections with Mycoplasma pneumoniae, cytomegalovirus, Epstein-Barr and influenza have also be correlated with GBS $^{3,9}$. Zika virus was identified as an associated virus after the epidemiological alert from the World Health Organization (WHO) during $2015^{10}$.

The clinical factors associated with unfavorable prognosis are severe motor deficit, respiratory impairment, cranial nerve involvement, autonomic nervous system dysfunction and impaired consciousness at the onset of the disease ${ }^{11}$. Leukocytosis, elevated transaminases, elevated serum creatinine, proteinuria, and axonal lesions have also been reported to be associated factors ${ }^{12}$. Histories of diarrhea and diabetes with absence of prior respiratory infection have also been found to be associated with worse outcomes at discharge ${ }^{13-15}$.

The WHO has reported that 3-5\% of GBS patients die from complications such as respiratory muscle paralysis, septicemia or pulmonary thrombosis ${ }^{16}$. In Peru, a mortality rate of $8.4 \%$ has been observed among patients older than 60 years ${ }^{7}$. A more significant number of cases have been correlated with infectious diseases ${ }^{7,17}$. The Peruvian Ministry of Health declared a state of emergency in relation to an outbreak consisting of 15 cases reported in the city of Trujillo-La Libertad over a four-week period during the summer of $2018^{18}$.

The principal aim of the present study was to determine associations between clinical-epidemiological characteristics on admission and the discharge outcomes among patients with GBS who survived until hospital discharge at Hospital Nacional Dos de Mayo (HNDM) in Lima, Peru, between 2011 and 2015. We also describe differences in the presence of some clinical-epidemiological characteristics according to the presentation season.

\section{METHODS}

For this retrospective observational study, we assessed 92 medical records from the Hemotherapy and Neurology service registries, relating to GBS patients who were therapeutic plasma exchange (TPE) candidates and who survived until hospital discharge between January 1, 2011, and December 31, 2015. Although these registries included 158 patients during this period (survivors plus non-survivors), we only evaluated the surviving patients because the physical records of the deceased patients were not available in our hospital unit.

We used the Brighton Collaboration's criteria (www.brightoncollaboration.org) to determine patient inclusion ${ }^{4}$. We excluded reports of patients with neuropathies caused by diabetes, alcohol, intoxications, neoplasms, human immunodeficiency virus or central nervous system disorders with several neurological deficits.

We recorded the following data: age, sex, disease onset date, clinical manifestations, severity (on admission, at nadir and at discharge), infectious history (gastrointestinal and respiratory), therapy with TPE and number of days of hospitalization. We categorized the seasonality as summer (January to March), autumn (April to June), winter (July to September) and spring (October to December). 
We scored the severity of functional status from 0 to 6 , in accordance with the HSS: $0=$ normal; $1=$ able to run with minor signs or symptoms of neuropathy; 2 = able to walk 10 $\mathrm{m}$ without support but not run; 3 = able to walk $10 \mathrm{~m}$ with aids; 4 = chair or bed; 5 = requiring assisted ventilation; and 6 = dead. For our analysis, patients with HSS 1 and 2 were deemed to have a mild deficit (MD), while those with 3 to 5 had a severe deficit $(\mathrm{SD})^{19}$.

We defined the discharge outcomes as an improvement if HSS decreased by at least one point from admission to hospital discharge and defined the hospital stay as prolonged if it was greater than 14 days, given that this length of time is a conservative estimate for performing complete TPE treatment $^{20}$.

We used the median to measure central trend and the interquartile range (first to third) to measure dispersion, for all quantitative variables, since these did not follow normal distribution. We represented categorical variables using their respective absolute values and percentages.

We used the chi-square test or Fisher's exact test to study differences between clinical-epidemiological characteristics according to the presentation season. We use univariate binomial logistic regression to assess the relationship between clinical-epidemiological characteristics and discharge outcomes represented by a prevalence ratio (PR). P-values below 0.05 were considered significant, and we presented the values with their $95 \%$ confidence interval (CI). Only sufficiently extreme results $(\mathrm{p}<0.2)$ were subjected to multivariate analysis for confounder adjustment. We use the STATA 16 statistical software, along with Excel 2019.

The Ethics Committee of the HNDM approved the protocol. The present study formed support for a thesis for obtaining the title of Physician, awarded by the Faculty of Medicine of the Universidad Nacional Mayor de San Marcos (UNMSM).

\section{RESULTS}

Among the 92 medical records included, 70.7\% (65/92) related to male patients and, thus, the male/female ratio was 2.4. The patients' median age was 44 years (Q1: 33; Q3: 58) (Table 1).

Concerning the data on admission clinical characteristics that was available, quadriparesis and hyporeflexia were the most characteristic manifestations, affecting 81.1\% (73/90) and $86.8 \%(79 / 91)$ of the patients, respectively. SD was present in $89.1 \%$ (82/92) of the patients, and $18.9 \%$ (17/90) of the patients required some oxygen therapy due to ventilatory impairment. Also, 64.4\% (56/87) of the patients showed normal sensory function, $51.2 \%(42 / 82)$ presented paresthesia, $30 \%$ (24/80) had ataxia and 20.5\% (18/88) presented autonomic dysfunction (cardiac arrhythmia and hypotension). Regarding other symptoms, 50.6\% (45/89) presented muscle pain, 26.7\% (24/90) presented radicular pain and 15.4\% (14/91) painful involvement of a cranial nerve. According to the HSS, 92.1\% (82/89) presented SD around the nadir or point of most significant deficit. The median time from the onset of symptoms to the nadir was seven days (Q1: 4; Q3: 11) (Table 1).

TPE was the treatment reported in $69.6 \%$ (64/92) of the medical records. The median time from the onset of symptoms to performing the TPE was 8.5 days (Q1: 5.5; Q3: 13) with a median of four cycles (Q1: 3; Q3: 4) per patient. At hospital discharge, $63.6 \%(56 / 88)$ of the patients had SD. The median length of hospitalization was 14 days (Q1: 11; Q3: 18), and we observed an improvement in $60.2 \%$ (53/88) of the cases (Table 1).

Table 1. Clinical-epidemiological characteristics at admission and outcomes at discharge among surviving patients with GBS.

\begin{tabular}{|c|c|c|}
\hline Variables & Total & $\mathrm{N}(\%)$ \\
\hline Demographics & 92 & \\
\hline$\geq 65$ years & & $12(13.0)$ \\
\hline Sex & 92 & \\
\hline Male & & $65(70.7)$ \\
\hline Infection history & 92 & \\
\hline Gastrointestinal & & $28(30.4)$ \\
\hline Respiratory & & $18(19.6)$ \\
\hline \multicolumn{3}{|l|}{ Clinical presentation } \\
\hline Motor compromise & 90 & \\
\hline Quadriparesis & & $73(81.1)$ \\
\hline Quadriplegia & & $8(8.9)$ \\
\hline Paraparesis & & $8(8.9)$ \\
\hline Paraplegia & & $1(1.1)$ \\
\hline Hyporeflexia & 91 & $79(86.8)$ \\
\hline Ventilatory involvement & 90 & $17(18.9)$ \\
\hline Sensitive impairment & 87 & \\
\hline Normal & & $56(64.4)$ \\
\hline Hyposensitivity & & $28(32.2)$ \\
\hline Hypersensitivity & & $3(3.5)$ \\
\hline Paresthesia & 82 & $42(51.2)$ \\
\hline Ataxia & 80 & $24(30.0)$ \\
\hline Autonomic dysfunction & 88 & $18(20.5)$ \\
\hline Cranial nerve compromise & 91 & $14(15.4)$ \\
\hline \multicolumn{3}{|l|}{ Other symptoms } \\
\hline Muscle pain & 89 & $45(50.6)$ \\
\hline Radicular pain & 90 & $24(26.7)$ \\
\hline \multicolumn{3}{|l|}{ Treatment } \\
\hline TPE use & 92 & $64(69.6)$ \\
\hline \multicolumn{3}{|l|}{ Discharge outcomes } \\
\hline Improvement & 88 & $53(60.2)$ \\
\hline Prolonged stay & 84 & $38(45.2)$ \\
\hline
\end{tabular}

TPE: therapeutic plasma exchange. 
Regarding the season, 58.7\% (54/92) of the cases occurred in the summer and winter. The largest number of cases occurred in July and August (25\%; 23/92); 17.8\% (5/28) of the cases with a gastrointestinal history occurred in August, while $33.3 \%(6 / 18)$ of the cases with a respiratory history occurred in February and September (Table 2 and Figure 1). Regarding differences in the frequencies of clinical characteristics according to the season, no statistically significant differences were found in relation to improvement in HSS ( $p$ $=0.462)$, prolonged stay $(\mathrm{p}=0.450)$, HSS at admission $(\mathrm{p}=$ $0.057)$, gastrointestinal infection history $(\mathrm{p}=0.734)$ or respiratory infection history $(\mathrm{p}=0.745)$ (Table 2).

The proportion of the patients with a gastrointestinal infection history who had a prolonged stay was higher than among non-infected patients (PR: 2.11; 95\% CI: 1.35 - 3.29). In the multivariate analysis, the proportion of the patients with gastrointestinal infection who had a prolonged stay continued to be higher (PR: 2.15; 95\% CI: 1.28 - 3.63) after adjustment for the presence of autonomic dysfunction. Also, the proportion with improvement of HSS was lower among patients who presented SD at hospital admission (PR: 0.43; 95\% CI: 0.28 - 0.67) and received TPE (PR: 0.55; 0.34 - 0.91). In the multivariate analysis, the proportion of the patients with improvement among those who had an SD at hospital admission continued to be lower (PR: 0.43; 95\% CI: 0.21 - 0.90) after adjustment for the time taken to reach maximum severity and after adjustment for TPE use (Table 3).

Table 2. Proportional differences in clinical-epidemiological characteristics at admission and outcomes at discharge according to season.

\begin{tabular}{|c|c|c|c|c|c|c|}
\hline & \multirow{2}{*}{ Total (\%) } & \multicolumn{4}{|c|}{ Season } & \multirow{2}{*}{$p$-value } \\
\hline & & Summer & Autumn & Winter & Spring & \\
\hline Number of cases & 92 & 27 & 21 & 27 & 17 & \\
\hline HSS at admission & 92 & & & & & $0.1^{*}$ \\
\hline Mild deficit & $10(10.8)$ & 2 & 1 & 2 & 5 & \\
\hline Severe deficit & $82(89.1)$ & 25 & 20 & 25 & 12 & \\
\hline \multicolumn{7}{|l|}{ Infectious history } \\
\hline Gastrointestinal & 92 & & & & & $0.7^{\star}$ \\
\hline No & $64(69.5)$ & 20 & 14 & 17 & 13 & \\
\hline Yes & $28(30.4)$ & 7 & 7 & 10 & 4 & \\
\hline Respiratory & 92 & & & & & $0.7 \dagger$ \\
\hline No & $74(80.4)$ & 20 & 17 & 22 & 15 & \\
\hline Yes & $18(19.5)$ & 7 & 4 & 5 & 2 & \\
\hline \multicolumn{7}{|c|}{ Discharge outcomes } \\
\hline Improvement & 88 & & & & & $0.4^{*}$ \\
\hline No & 35 (39.7) & 13 & 6 & 9 & 7 & \\
\hline Yes & $53(60.2)$ & 12 & 13 & 18 & 10 & \\
\hline Prolonged stay & 84 & & & & & $0.4 \dagger$ \\
\hline No & $46(54.7)$ & 16 & 9 & 11 & 10 & \\
\hline Yes & $38(45.2)$ & 8 & 10 & 13 & 7 & \\
\hline
\end{tabular}

HSS: Hughes severity scale; * Chi-square test; † Fisher's exact test.

Table 3. Clinical-epidemiological characteristics at admission that presented associations with outcomes at discharge among surviving patients with GBS.

\begin{tabular}{|c|c|c|c|c|c|c|c|c|}
\hline \multirow{3}{*}{ Variables } & \multicolumn{3}{|c|}{ Prolonged hospital stay } & \multirow{3}{*}{$\begin{array}{c}\text { Adjusted PR } \\
(\mathrm{Cl} 95 \%) \dagger\end{array}$} & \multicolumn{3}{|c|}{ Improvement } & \multirow{3}{*}{$\begin{array}{c}\text { Adjusted PR } \\
(95 \% \mathrm{Cl}) \dagger+\end{array}$} \\
\hline & No & Yes & & & No & Yes & & \\
\hline & $\mathrm{N}(\%)$ & $\mathrm{N}(\%)$ & PR (95\% Cl) & & $\mathrm{N}(\%)$ & $\mathrm{N}(\%)$ & PR (95\% Cl) & \\
\hline Age (years)* & $\begin{array}{c}43 \\
(33-54)\end{array}$ & $\begin{array}{c}46 \\
(36-63)\end{array}$ & $\begin{array}{c}1.01 \\
(0.99-1.03)\end{array}$ & $\star \star$ & $\begin{array}{c}43 \\
(33-57)\end{array}$ & $\begin{array}{c}46 \\
(24-58)\end{array}$ & $\begin{array}{c}0.99 \\
(0.97-1.01)\end{array}$ & $\star \star *$ \\
\hline$<65$ years & $\begin{array}{c}42 \\
(57.5)\end{array}$ & $\begin{array}{c}31 \\
(42.5)\end{array}$ & Ref & Ref & $\begin{array}{c}5 \\
(50.0)\end{array}$ & $\begin{array}{c}5 \\
(50.0)\end{array}$ & Ref & $\star \star$ \\
\hline $\begin{array}{l}65 \text { or more } \\
\text { years }\end{array}$ & $\begin{array}{c}4 \\
(36.4)\end{array}$ & $\begin{array}{c}7 \\
(63.6)\end{array}$ & $\begin{array}{c}1.50 \\
(0.89-2.53)\end{array}$ & $\star \star$ & $\begin{array}{c}30 \\
(38.5)\end{array}$ & $\begin{array}{c}48 \\
(61.5)\end{array}$ & $\begin{array}{c}1.30 \\
(0.66-2.58)\end{array}$ & $\star \star$ \\
\hline
\end{tabular}


Table 3. Cont.

\begin{tabular}{|c|c|c|c|c|c|c|c|c|}
\hline \multirow{3}{*}{ Variables } & \multicolumn{3}{|c|}{ Prolonged hospital stay } & \multirow{3}{*}{$\begin{array}{l}\text { Adjusted PR } \\
(\mathrm{Cl} \text { 95\%) } †\end{array}$} & \multicolumn{3}{|c|}{ Improvement } & \multirow{3}{*}{$\begin{array}{c}\text { Adjusted PR } \\
(95 \% \mathrm{Cl}) \dagger+\end{array}$} \\
\hline & & Yes & & & & Yes & & \\
\hline & $\mathrm{N}(\%)$ & $\mathrm{N}(\%)$ & PR (95\% Cl) & & $\mathrm{N}(\%)$ & $\mathrm{N}(\%)$ & PR $(95 \% \mathrm{Cl})$ & \\
\hline \multicolumn{9}{|l|}{ Sex } \\
\hline Female & $\begin{array}{c}11 \\
(47.8)\end{array}$ & $\begin{array}{c}12 \\
(52.2)\end{array}$ & Ref & Ref & $\begin{array}{c}17 \\
(65.4)\end{array}$ & $\begin{array}{c}9 \\
(34.6)\end{array}$ & Ref & Ref \\
\hline Male & $\begin{array}{c}35 \\
(57.4)\end{array}$ & $\begin{array}{c}26 \\
(42.6) \\
\end{array}$ & $\begin{array}{c}0.82 \\
(0.50-1.33)\end{array}$ & ** & $\begin{array}{c}36 \\
(58.1)\end{array}$ & $\begin{array}{c}26 \\
(41.9)\end{array}$ & $\begin{array}{c}1.21 \\
(0.66-2.22)\end{array}$ & ** \\
\hline \multicolumn{9}{|c|}{ Gastrointestinal infection } \\
\hline No & $\begin{array}{c}38 \\
(66.7)\end{array}$ & $\begin{array}{c}19 \\
(33.3)\end{array}$ & Ref & Ref & $\begin{array}{c}35 \\
(56.5)\end{array}$ & $\begin{array}{c}27 \\
(43.5)\end{array}$ & Ref & Ref \\
\hline Yes & $\begin{array}{c}8 \\
(29.6) \\
\end{array}$ & $\begin{array}{c}19 \\
(70.4)\end{array}$ & $\begin{array}{c}2.11 \\
(1.35-3.29)\end{array}$ & $\begin{array}{c}2.1 \\
(1.28-3.63)\end{array}$ & $\begin{array}{c}18 \\
(69.2)\end{array}$ & $\begin{array}{c}8 \\
(30.8) \\
\end{array}$ & $\begin{array}{c}0.71 \\
(0.37-1.35)\end{array}$ & $\star *$ \\
\hline \multicolumn{9}{|c|}{ Respiratory infection } \\
\hline No & $\begin{array}{c}39 \\
(58.2)\end{array}$ & $\begin{array}{c}28 \\
(41.8)\end{array}$ & Ref & Ref & $\begin{array}{c}41 \\
(57.7)\end{array}$ & $\begin{array}{c}30 \\
(42.3)\end{array}$ & Ref & Ref \\
\hline Yes & $\begin{array}{c}7 \\
(41.2)\end{array}$ & $\begin{array}{c}10 \\
(58.8)\end{array}$ & $\begin{array}{c}1.41 \\
(0.86-2.30)\end{array}$ & $\star \star$ & $\begin{array}{c}12 \\
(70.6)\end{array}$ & $\begin{array}{c}5 \\
(29.4)\end{array}$ & $\begin{array}{c}0.70 \\
(0.32-1.53)\end{array}$ & $* *$ \\
\hline \multicolumn{9}{|c|}{ HSS at admission } \\
\hline Mild deficit & $\begin{array}{c}8 \\
(80.0)\end{array}$ & $\begin{array}{c}2 \\
(20.0)\end{array}$ & Ref & Ref & $\begin{array}{c}2 \\
(20.0)\end{array}$ & $\begin{array}{c}8 \\
(80.0)\end{array}$ & Ref & Ref \\
\hline $\begin{array}{l}\text { Severe } \\
\text { deficit }\end{array}$ & $\begin{array}{c}38 \\
(51.4)\end{array}$ & $\begin{array}{c}36 \\
(48.6)\end{array}$ & $\begin{array}{c}2.43 \\
(0.68-8.65)\end{array}$ & $\star *$ & $\begin{array}{c}51 \\
(65.4)\end{array}$ & $\begin{array}{c}27 \\
(34.6)\end{array}$ & $\begin{array}{c}0.43 \\
(0.28-0.67)\end{array}$ & $\begin{array}{c}0.43 \\
(0.21-0.90)\end{array}$ \\
\hline $\begin{array}{l}\text { Time to } \\
\text { maximum } \\
\text { severity } \\
\text { (days)* }\end{array}$ & $\begin{array}{c}7 \\
(4-10)\end{array}$ & $\begin{array}{c}7 \\
(5-11)\end{array}$ & $\begin{array}{c}1.03 \\
(0.98-1.08)\end{array}$ & ** & $\begin{array}{c}7 \\
(3-9)\end{array}$ & $\begin{array}{c}8 \\
(5-11)\end{array}$ & $\begin{array}{c}0.96 \\
(0.90-1.02)\end{array}$ & $\begin{array}{c}0.98 \\
(0.91-1.04)\end{array}$ \\
\hline \multicolumn{9}{|c|}{ Ventilatory impairment } \\
\hline No & $\begin{array}{c}40 \\
(58.0)\end{array}$ & $\begin{array}{c}29 \\
(42.0)\end{array}$ & Ref & Ref & $\begin{array}{c}43 \\
(61.4)\end{array}$ & $\begin{array}{c}27 \\
(38.6)\end{array}$ & Ref & Ref \\
\hline Yes & $\begin{array}{c}5 \\
(38.5)\end{array}$ & $\begin{array}{c}8 \\
(61.5)\end{array}$ & $\begin{array}{c}1.46 \\
(0.88-2.45)\end{array}$ & $\star \star$ & $\begin{array}{c}10 \\
(58.8)\end{array}$ & $\begin{array}{c}7 \\
(41.2)\end{array}$ & $\begin{array}{c}1.07 \\
(0.56-2.03)\end{array}$ & $\star \star$ \\
\hline \multicolumn{9}{|c|}{ Autonomic dysfunction } \\
\hline No & $\begin{array}{c}37 \\
(56.9)\end{array}$ & $\begin{array}{c}28 \\
(43.1)\end{array}$ & Ref & Ref & $\begin{array}{c}42 \\
(61.8)\end{array}$ & $\begin{array}{c}26 \\
(38.2)\end{array}$ & Ref & Ref \\
\hline Yes & $\begin{array}{c}5 \\
(33.3) \\
\end{array}$ & $\begin{array}{c}10 \\
(66.7)\end{array}$ & $\begin{array}{c}1.55 \\
(0.98-2.44)\end{array}$ & $\begin{array}{c}0.93 \\
(0.56-1.54)\end{array}$ & $\begin{array}{c}11 \\
(64.7)\end{array}$ & $\begin{array}{c}6 \\
(35.3) \\
\end{array}$ & $\begin{array}{c}0.92 \\
(0.45-1.89)\end{array}$ & $\star *$ \\
\hline \multicolumn{9}{|c|}{ Cranial nerve impairment } \\
\hline No & $\begin{array}{c}39 \\
(55.7)\end{array}$ & $\begin{array}{c}31 \\
(44.3)\end{array}$ & Ref & Ref & $\begin{array}{c}43 \\
(58.1)\end{array}$ & $\begin{array}{c}31 \\
(41.9)\end{array}$ & Ref & Ref \\
\hline Yes & $\begin{array}{c}6 \\
(46.2) \\
\end{array}$ & $\begin{array}{c}7 \\
(53.8) \\
\end{array}$ & $\begin{array}{c}1.22 \\
(0.69-2.15)\end{array}$ & ** & $\begin{array}{c}9 \\
(69.2)\end{array}$ & $\begin{array}{c}4 \\
(30.8) \\
\end{array}$ & $\begin{array}{c}0.73 \\
(0.31-1.74)\end{array}$ & $\star \star$ \\
\hline \multicolumn{9}{|l|}{ TPE use } \\
\hline No & $\begin{array}{c}14 \\
(58.3)\end{array}$ & $\begin{array}{c}10 \\
(41.7)\end{array}$ & Ref & Ref & $\begin{array}{c}12 \\
(42.9)\end{array}$ & $\begin{array}{c}16 \\
(57.1)\end{array}$ & Ref & Ref \\
\hline Yes & $\begin{array}{c}32 \\
(53.3)\end{array}$ & $\begin{array}{c}28 \\
(46.7)\end{array}$ & $\begin{array}{c}1.12 \\
(0.65-1.94)\end{array}$ & ** & $\begin{array}{c}41 \\
(68.3)\end{array}$ & $\begin{array}{c}19 \\
(31.7)\end{array}$ & $\begin{array}{c}0.55 \\
(0.34-0.91)\end{array}$ & $\begin{array}{c}0.52 \\
(0.27-1.00)\end{array}$ \\
\hline $\begin{array}{l}\text { TPE } \\
\text { sessions* }\end{array}$ & $\begin{array}{c}4 \\
(3-4)\end{array}$ & $\begin{array}{c}4 \\
(4-4)\end{array}$ & $\begin{array}{c}1.30 \\
(0.82-2.05)\end{array}$ & ** & $\begin{array}{c}4 \\
(3-4)\end{array}$ & $\begin{array}{c}4 \\
(4-4)\end{array}$ & $\begin{array}{c}1.19 \\
(0.57-2.49)\end{array}$ & $\star \star$ \\
\hline
\end{tabular}

PR: prevalence ratio; HSS: Hughes severity scale;TPE: therapeutic plasma exchange; * Median (Q1 - Q3). ** No adjustment needed; † Adjusted for gastrointestinal infection and autonomic dysfunction; †† Adjusted for HSS at admission, time to maximum severity and TPE use. 


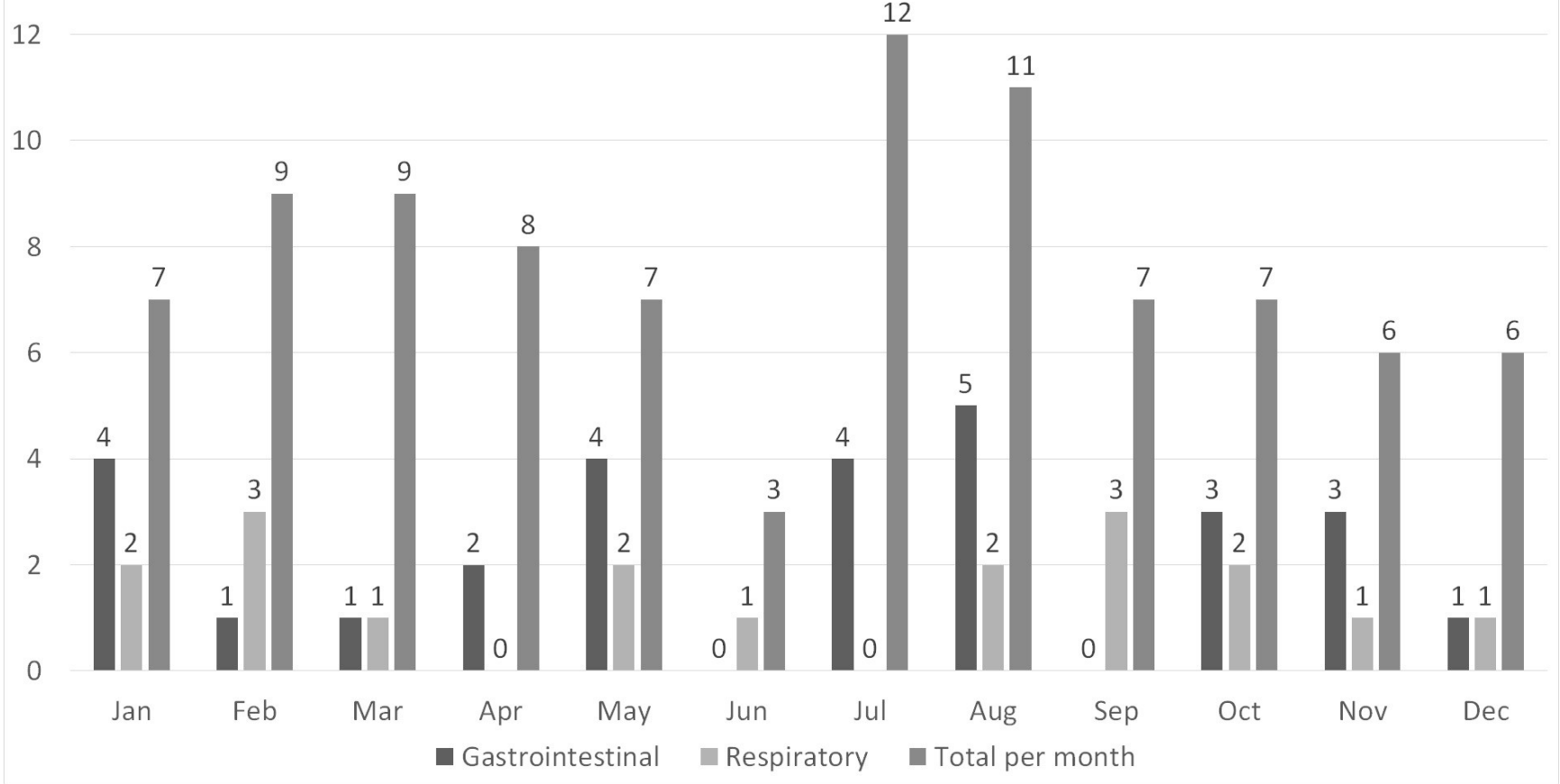

Figure 1. Monthly distribution of the number of GBS cases according to infectious history.

\section{DISCUSSION}

At the time of hospital discharge, a large percentage of the patients persisted with an SD. One crucial factor relating to this may have been a lack of resources for timely access to specific treatment or rehabilitation services. Moreover, clinical improvement of GBS was not immediate. We determined that there was an association between higher prevalence of prolonged stay and presence of gastrointestinal infection: patients with histories of infection usually present greater severity of disease ${ }^{3}$. In another study, the prevalence of improvement was lower among patients who had an SD at admission for their critical condition and therefore underwent prolonged continuous monitoring in intensive care units $^{21}$.

Among all the patients included in our study, males were more affected. This was the same as in other studies, in which males accounted for over $50 \%$ of all the cases ${ }^{5,22,23}$. Our cases had a median age of 44 years, which was close to the average of some other studies, which ranged from 40 to 50 years ${ }^{15,24}$. However, in other reports, the average age was over 50 years $^{22,25,26}$.

At hospital admission, quadriparesis and alteration of tendon reflexes were the most frequent clinical features. These correlated with the typical findings of GBS $8,12,22,24$. Most of our patients had an SD greater than that of other cohorts $(35.8-61.7 \%)^{12,24}$. As expected, approximately 20\% of our patients presented some ventilatory alteration, which leads to the risk of needing care in an intensive care unit ${ }^{4,27}$. The time between the onset of symptoms in our cases and the nadir coincided with that of other reports: this is important because it could serve as a time reference for timely management ${ }^{22}$. Autonomic dysfunction occurred in one-fifth of our patients, which was lower than in other reports ${ }^{28}$.

All GBS patients with an HSS score of more than two need to receive specific treatment to improve disability over the short and long terms ${ }^{29}$. Among our patients who received TPE, the majority started this within the first two weeks, with enough cycles. This treatment was as recommended by the Pan-American Health Organization, the American Apheresis Society (ASFA) and a previous report from the HNDM ${ }^{10,20,30}$. However, not all patients improved during hospitalization, given that the time taken to reach improvement may be longer than the hospital stay ${ }^{29}$.

More than half of our cases occurred in summer and winter. These results were similar in seasonality to those of some studies ${ }^{6,8,24,31}$ but differed from other reports in which the highest number of cases occurred in spring and the second highest in summer ${ }^{5,23,32,33}$. This difference may have been because Peru is a tropical country without the clear seasonal differences that are seen in temperate countries. Recent studies have suggested that this seasonal variation is due to sudden changes in temperatures, which would contribute to the development of gastrointestinal or respiratory infections ${ }^{5,23}$. There were no significant differences in the proportion of improvement according to the season, but the improvement rate was lower in the summer (52\%) and spring (41\%), and higher in the autumn (68.4\%) and winter (68.4\%). Despite 
this lack of statistically significant difference, we suggest that resource allocations should differ between the seasons such that they should be greater in seasons with a more significant trend of presentation of cases.

There were some significant limitations to our study relating to lack of data: no explicit records of patients who received immunoglobulin were available; the average time that elapsed until treatment was started was not completely clear; and there was also no data on adverse events, long-term followup, cerebrospinal fluid analysis or nerve conduction studies. In addition, there was no detailed information about the reasons for prolonged stay (i.e., whether this was because of the disease itself or because of other complications). Therefore, there was a high risk of bias because of incomplete data and records, since this was a study based on secondary medical records prepared by different specialists. We standardized the information collected, and this was done by a single expert in clinical neurology. The medical records did not show any routine use of scales such as EGRIS and EGOS, which therefore limits the usefulness of our data for prognostic purposes. It is important to emphasize again that since we used a list of TPE candidates at the time of admission, we did not include patients who received intravenous immunoglobulin as their treatment.

In conclusion, histories of gastrointestinal infection and SD on admission showed an association with longer hospital stays and less improvement in survival among these Peruvian patients with GBS at hospital discharge. Therefore, there is a need to describe patients' history and severity of infection in greater detail at hospital admission, in order to improve the detection of patients who potentially have a poor prognosis. Further longitudinal studies are needed in order to confirm these associations.

It would be opportune to create a prospective multicenter surveillance system with the aim of homogenizing case registration, case notification and data analysis among GBS patients in a low-income environment such as Peru.

\section{ACKNOWLEDGEMENT}

The authors appreciate the external support of Dr. Luis Palma-García for providing the registration list and Dr. Julio Perez-Villegas for reviewing the medical records as an expert neurologist.

\section{REFERENCES}

1. Asbury AK, Cornblath DR. Assessment of current diagnostic criteria for Guillain-Barré syndrome. Ann Neurol. 1990;27(Suppl):S21-4. https://doi.org/10.1002/ana.410270707

2. van den Berg B, Walgaard C, Drenthen J, Fokke C, Jacobs BC, van Doorn PA. Guillain-Barré syndrome: pathogenesis, diagnosis, treatment and prognosis. Nat Rev Neurol. 2014 Aug;10(8):469-82. https://doi.org/10.1038/nrneurol.2014.121

3. Willison HJ, Jacobs BC, van Doorn PA. Guillain-Barré syndrome. Lancet. 2016 Aug 13;388(10045):717-27. https://doi.org/10.1016/ S0140-6736(16)00339-1

4. Fokke C, van den Berg B, Drenthen J, Walgaard C, van Doorn PA, Jacobs BC. Diagnosis of Guillain-Barré syndrome and validation of Brighton criteria. Brain. 2014 Jan;137(Pt 1):33-43. https://doi. org/10.1093/brain/awt285

5. Shrivastava M, Nehal S, Seema N. Guillain-Barre syndrome: Demographics, clinical profile \& seasonal variation in a tertiary care centre of central India. Indian J Med Res. 2017 Feb;145(2):203-208. https://doi.org/10.4103/ijmr.ijmr_995_14

6. Rivera-Lillo G, Torres-Castro R, Burgos PI, Varas-Díaz G, Vera-Uribe R, Puppo H, Hernández M. Incidence of Guillain-Barré syndrome in Chile: a population-based study. J Peripher Nerv Syst. 2016 Dec;21(4):339-344. https://doi.org/10.1111/jns.12182

7. Munayco CV, Soto Cabezas MG, Reyes MF, Arica Gutiérrez JA, Napanga Saldaña O. Epidemiología del síndrome de guillain-barré en el Perú. Rev Peru Med Exp Salud Publica. 2019 Jan-Mar;36(1):10-16. https://doi.org/10.17843/rpmesp.2019.361.3729

8. Ballón-Manrique B, Campos-Ramos N. Características clínicas y paraclínicas del Síndrome de Guillain-Barré en el Hospital Regional Lambayeque. Rev Neuropsiquiatr. 2017;80(1):22-26. https://doi. org/10.20453/rnp.v80i1.3056

9. Costa ACD. Síndrome de Guillain-Barré: uma revisão integrativa de literatura e de dados do sistema único de saúde [dissertation]. Brasília, BR: UnB; 2016
10. Organización Panamericana de la Salud. Recomendaciones prácticas para la implementación de las guías de detección y atención del síndrome de Guillain-Barré relacionado con Zika en la Región de las Américas. 2016. Washington: OPS.

11. Walgaard C, Lingsma HF, Ruts L, Drenthen J, van Koningsveld R, Garssen MJ, et al. Prediction of respiratory insufficiency in GuillainBarré syndrome. Ann Neurol. 2010 Jun;67(6):781-7. https://doi. org/10.1002/ana.21976

12. González-Suárez I, Sanz-Gallego I, Rodríguez de Rivera FJ, Arpa J. Guillain-Barré syndrome: natural history and prognostic factors: a retrospective review of 106 cases. BMC Neurol. 2013 Jul 22;13:95. https://doi.org/10.1186/1471-2377-13-95

13. Bae JS, Kim YJ, Kim JK. Diabetes mellitus exacerbates the clinical and electrophysiological features of Guillain-Barré syndrome. Eur J Neurol. 2016 Mar;23(3):439-46. https://doi.org/10.1111/ene.12885

14. Kuwabara S, Ogawara K, Misawa S, Koga M, Mori M, Hiraga A, et al. Does Campylobacter jejuni infection elicit "demyelinating” GuillainBarre syndrome? Neurology. 2004 Aug 10;63(3):529-33. https://doi. org/10.1212/01.wnl.0000133205.05169.04

15. Zhang Y, Zhao Y, Wang Y. Prognostic factors of Guillain-Barré syndrome: a 111-case retrospective review. Chin Neurosurg J. 2018 Jun 18;4:14. https://doi.org/10.1186/s41016-018-0122-y

16. World Health Organization [Internet]. Guillain-Barré syndrome updated 2016 October 31. [cited 2021 August 23]. Available from: https://www.who.int/news-room/fact-sheets/detail/guillain-barrésyndrome

17. Martinez JC, Misnaza SP. Mortalidad por enfermedades huérfanas en Colombia, 2008-2013. Biomedica. 2018;38(2):198-0. https://doi. org/10.7705/biomedica.v38i0.3876

18. Díaz-Soto S, Chavez K, Chaca A, Alanya J, Tirado-Hurtado I. Outbreak of Guillain-Barre syndrome in Peru. eNeurologicalSci. 2019 Feb 7;14:89-90. https://doi.org/10.1016/j.ensci.2019.02.001 
19. Alva-Diaz C, Mori N, Pacheco-Barrios K, Velásquez-Rimachi V, RiveraTorrejon O, Huerta-Rosario CA, et al. Guía de práctica clínica para el diagnóstico y tratamiento del paciente con síndrome de GuillainBarré, Perú, 2018. Neurología Argentina. 2020;12(1):36-48 https://doi. org/10.1016/j.neuarg.2019.09.006

20. Schwartz J, Padmanabhan A, Aqui N, Balogun RA, Connelly-Smith $L$, Delaney M, et al. Guidelines on the Use of Therapeutic Apheresis in Clinical Practice-Evidence-Based Approach from the Writing Committee of the American Society for Apheresis: The Seventh Special Issue. J Clin Apher. 2016 Jun;31(3):149-62. https://doi. org/10.1002/jca.21470.

21. Manrique GG, Bahamon GG, Motta AG, Ramos CFR. Síndrome Guillain-Barré: un mirada actual. RFS Revista Facultad de Salud. 2016;8(2):38-45. https://doi.org/10.25054/rfs.v8i2.1408

22. Martic V, Bozovic I, Berisavac I, Basta I, Peric S, Babic M, et al. ThreeYear Follow-Up Study in Patients with Guillain-Barré Syndrome. Can J Neurol Sci. 2018 May;45(3):269-274. https://doi.org/10.1017/ cjn.2018.12

23. Momen AA, Shakurnia A. The Epidemiology of Guillain-Barré Syndrome in Children under 15 Years Old in Southwest Iran. Biomed Hub. 2017 Oct 10;2(3):1-8. https://doi.org/10.1159/000480693

24. Sudulagunta SR, Sodalagunta MB, Sepehrar M, Khorram H, Bangalore Raja SK, Kothandapani S, et al. Guillain-Barré syndrome: clinical profile and management. Ger Med Sci. 2015 Sep 21;13:16. https://doi.org/10.3205/000220

25. Dirlikov E, Major CG, Medina NA, Lugo-Robles R, Matos D, MuñozJordan JL, et al. Clinical Features of Guillain-Barré Syndrome With vs Without Zika Virus Infection, Puerto Rico, 2016.JAMA Neurol. 2018 Sep 1;75(9):1089-1097. https://doi.org/10.1001/ jamaneurol.2018.1058
26. Peric S, Milosevic V, Berisavac I, Stojiljkovic O, Beslac-Bumbasirevic L, Marjanovic I, et al. Clinical and epidemiological features of GuillainBarré syndrome in the Western Balkans. J Peripher Nerv Syst. 2014 Dec;19(4):317-21. https://doi.org/10.1111/jns.12096

27. Netto AB, Taly AB, Kulkarni GB, Rao UG, Rao S. Mortality in mechanically ventilated patients of Guillain Barré Syndrome. Ann Indian Acad Neurol. 2011 Oct;14(4):262-6. https://doi. org/10.4103/0972-2327.91942

28. Chakraborty T, Kramer CL, Wijdicks EFM, Rabinstein AA. Dysautonomia in Guillain-Barré Syndrome: Prevalence, Clinical Spectrum, and Outcomes. Neurocrit Care. 2020 Feb;32(1):113-120. https://doi.org/10.1007/s12028-019-00781-w

29. Chevret S, Hughes RA, Annane D. Plasma exchange for Guillain-Barré syndrome. Cochrane Database Syst Rev. 2017 Feb 27;2(2):CD001798. https://doi.org/10.1002/14651858.CD001798.pub3

30. Palma-Garcia L, Velásquez-Rimachi V, Pezo-Pezo A, Roig J, PerezVillegas J. Therapeutic plasma exchange: Experience in a third level hospital, 2013-2016, Lima (Peru). J Clin Apher. 2018 Aug;33(4):480485. https://doi.org/10.1002/jca.21623

31. Webb AJ, Brain SA, Wood R, Rinaldi S, Turner MR. Seasonal variation in Guillain-Barré syndrome: a systematic review, meta-analysis and Oxfordshire cohort study. J Neurol Neurosurg Psychiatry. 2015 Nov;86(11):1196-201. https://doi.org/10.1136/jnnp-2014-309056

32. Cheng BC, Chang WN, Chang CS, Chee CY, Huang CR, Chen JB, et al. Guillain-Barré syndrome in southern Taiwan: clinical features, prognostic factors and therapeutic outcomes. Eur J Neurol. 2003 Nov;10(6):655-62. https://doi.org/10.1046/j.1468-1331.2003.00683.x

33. Chroni E, Papapetropoulos S, Gioldasis G, Ellul J, Diamadopoulos N, Papapetropoulos T. Guillain-Barré syndrome in Greece: seasonality and other clinico-epidemiological features. Eur J Neurol. 2004 Jun;11(6):383-8. https://doi.org/10.1111/j.1468-1331.2004.00799.x 